\title{
IL13RA1 wt Allele
}

National Cancer Institute

\section{Source}

National Cancer Institute. IL13RA1 wt Allele. NCI Thesaurus. Code C51358.

Human IL13RA1 wild-type allele is located within Xq24 and is approximately $67 \mathrm{~kb}$ in length. This allele, which encodes interleukin-13 receptor subunit alpha-1 protein, is involved in both tyrosine kinase signal transduction and in the transcriptional activation of other tyrosine kinase genes, such as JAK1, STAT 3 and STAT 6. 